4

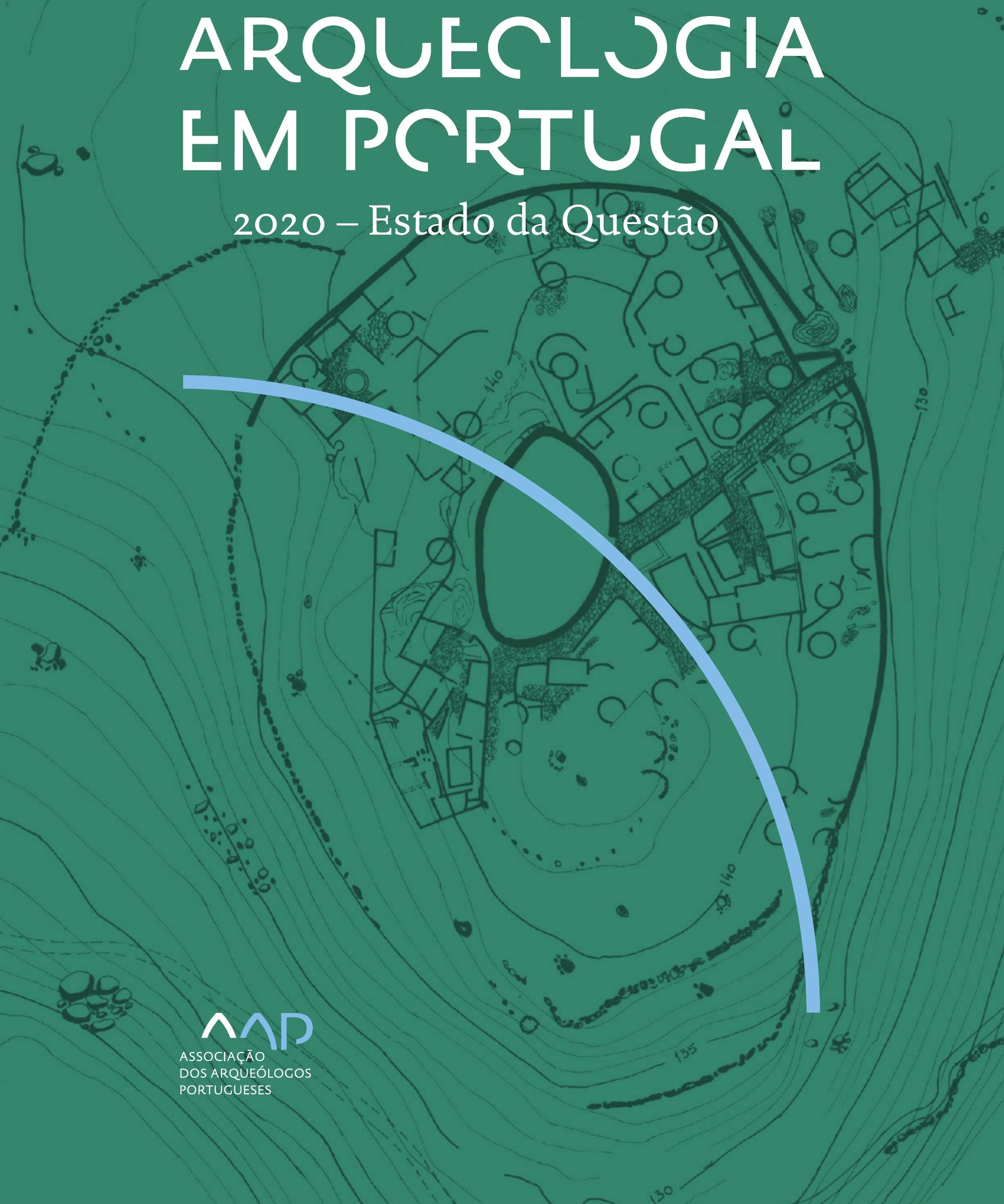


Coordenação editorial: José Morais Arnaud, César Neves e Andrea Martins Design gráfico: Flatland Design

AAP - ISBN: 978-972-9451-89-8

CITCEM - ISBN: 978-989-8970-25-1

Associação dos Arqueólogos Portugueses e CITCEM

Lisboa, 2020

O conteúdo dos artigos é da inteira responsabilidade dos autores. Sendo assim a Associação dos Arqueólogos Portugueses declina qualquer responsabilidade por eventuais equívocos ou questões de ordem ética e legal.

Desenho de capa:

Planta do castro de Monte Mozinho (Museu Municipal de Penafiel).

\section{$\hat{\wedge} \mathrm{P}$}

DOS ARQUEÓLOGOS PORTUGUESES

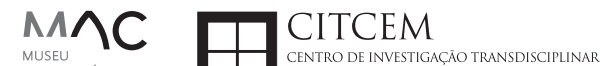
MUSEU
ARQUELLÓGICO
DO CARMO
U.PORTO

FLUP FACULDADE DE LETRAS
UNIVERSIDADE DO PORTO

Apoio

EC para a Ciência 


\section{Índice}

15 Prefácio

José Morais Arnaud

\section{Historiografia e Teoria}

17 Território, comunidade, memória e emoção: a contribuição da história da arqueologia (algumas primeiras e breves reflexões)

Ana Cristina Martins

25 Como descolonizar a arqueologia portuguesa?

Rui Gomes Coelho

41 Arqueologia e Modernidade: uma revisitação pessoal e breve de alguns aspetos da obra homónima de Julian Thomas de 2004

Vítor Oliveira Jorge

57 Dados para a História das Mulheres na Arqueologia portuguesa, dos finais do século XIX aos inícios do século XX: números, nomes e tabelas

Filipa Dimas / Mariana Diniz

73 Retractos da arqueologia portuguesa na imprensa: (in)visibilidades no feminino

Catarina Costeira / Elsa Luís

85 Arqueologia e Arqueólogos no Norte de Portugal Jacinta Bugalhão

101 Vieira Guimarães (1864-1939) e a arqueologia em Tomar: uma abordagem sobre o território e as gentes

João Amendoeira Peixoto / Ana Cristina Martins

115 Os memoráveis? A arqueologia algarvia na imprensa nacional e regional na presente centúria (2001-2019): características, visões do(s) passado(s) e a arqueologia

enquanto marca

Frederico Agosto / João Silva

129 A Evolução da Arqueologia Urbana e a Valorização Patrimonial no Barlavento Algarvio: Os casos de Portimão e Silves

Artur Mateus / Diogo Varandas / Rafael Boavida

\section{Gestão, Valorização e Salvaguarda do Património}

145 O Caderno Reivindicativo e as condições de trabalho em Arqueologia Miguel Rocha / Liliana Matias Carvalho / Regis Barbosa / Mauro Correia / Sara Simões / Jacinta Bugalhão / Sara Brito / Liliana Veríssimo Carvalho / Richard Peace / Pedro Peça / Cézer Santos

155 Os Estudos de Impacte Patrimonial como elemento para uma estratégia sustentável de minimização de impactes no âmbito de reconversões agrícolas Tiago do Pereiro

165 Salvaguarda de Património arqueológico em operações florestais: gestão e sensibilização Filipa Bragança / Gertrudes Zambujo / Sandra Lourenço / Belém Paiva / Carlos Banha / Frederico Tatá Regala / Helena Moura / Jacinta Bugalhão / João Marques / José Correia / Pedro Faria / Samuel Melro

179 Os valores do Património: uma investigação sobre os Sítios Pré-históricos de Arte Rupestre do Vale do Rio Côa e de Siega Verde José Paulo Francisco 
189 Conjugando recursos arqueológicos e naturais para potenciar as visitas ao Geoparque Litoral de Viana do Castelo (Noroeste de Portugal)

Hugo A. Sampaio / Ana M.S. Bettencourt / Susana Marinho / Ricardo Carvalhido

203 Áreas de Potencial Arqueológico na Região do Médio Tejo: Modelo Espacial Preditivo Rita Ferreira Anastácio / Ana Filipa Martins / Luiz Oosterbeek

223 Património Arqueológico e Gestão Territorial: O contributo da Arqueologia para a revisão do PDM de Avis

Ana Cristina Ribeiro

237 A coleção arqueológica do extinto Museu Municipal do Porto - Origens, Percursos e Estudos

Sónia Couto

251 Valpaços - uma nova carta arqueológica

Pedro Pereira / Maria de Fátima Casares Machado

263 Arqueologia na Cidade de Peniche

Adriano Constantino / Luís Rendeiro

273 Arqueologia Urbana: a cidade de Lagos como caso de Estudo Cátia Neto

285 Estratégias de promoção do património cultural subaquático nos Açores. O caso da ilha do Faial

José Luís Neto / José Bettencourt / Luís Borges / Pedro Parreira

297 Carta Arqueológica da Cidade Velha: Uma primeira abordagem

Jaylson Monteiro / Nireide Tavares / Sara da Veiga / Claudino Ramos / Edson Brito /

Carlos Carvalho / Francisco Moreira / Adalberto Tavares

311 Antropologia Virtual: novas metodologias para a análise morfológica e funcional Ricardo Miguel Godinho / Célia Gonçalves

\section{Didáctica da Arqueologia}

327 Como os projetos de Arqueologia podem contribuir para uma comunidade culturalmente mais consciente Alexandra Figueiredo / Claúdio Monteiro / Adolfo Silveira / Ricardo Lopes

337 Educação Patrimonial - Um cidadão esclarecido é um cidadão ativo! Ana Paula Almeida

351 A aproximação da Arqueologia à sala de aula: um caso de estudo no $3^{\circ}$ ciclo do Ensino Básico Luís Serrão Gil

363 Arqueologia 3.o - Pensar e comunicar a Arqueologia para um futuro sustentável Mónica Rolo

377 “Conversa de Arqueólogos" - Divulgar a Arqueologia em tempos de Pandemia Diogo Teixeira Dias

389 Escola Profissional de Arqueologia: desafios e oportunidades Susana Nunes / Dulcineia Pinto / Júlia Silva / Ana Mascarenhas

399 Os Museus de Arqueologia e os Jovens: a oferta educativa para o público adolescente Beatriz Correia Barata / Leonor Medeiros

411 O museu universitário como mediador entre a ciência e a sociedade: o exemplo da secção de arqueologia no Museu de História Natural e da Ciência da Universidade do Porto (MHNC-UP)

Rita Gaspar 
421 Museu de Lanifícios: Real Fábrica de Panos. Atividades no âmbito da Arqueologia Beatriz Correia Barata / Rita Salvado

427 Arqueologia Pública e o caso da localidade da Mata (Torres Novas) Cláudia Manso / Ana Rita Ferreira / Cristiana Ferreira / Vanessa Cardoso Antunes

431 Do sítio arqueológico ao museu: um percurso (também) didático Lídia Fernandes

447 Estão todos convidados para a Festa! E para dançar também... O projecto do Serviço Educativo do Museu Arqueológico do Carmo na $5^{\underline{a}}$ Edição da Festa da Arqueologia Rita Pires dos Santos

459 O “Clã de Carenque”, um projeto didático de arqueologia Eduardo Gonzalez Rocha

469 Mediação cultural: peixe que puxa carroça nas Ruínas Romanas de Troia Inês Vaz Pinto / Ana Patrícia Magalhães / Patrícia Brum / Filipa Santos

481 Didática Arqueológica, experiências do Projeto Mértola Vila Museu Maria de Fátima Palma / Clara Rodrigues / Susana Gómez / Lígia Rafael

\section{Arte Rupestre}

497 Os inventários de arte rupestre em Portugal Mila Simões de Abreu

513 O projeto FIRST-ART - conservação, documentação e gestão das primeiras manifestações de arte rupestre no Sudoeste da Península Ibérica: as grutas do Escoural e Maltravieso Sara Garcês / Hipólito Collado / José Julio García Arranz / Luiz Oosterbeek / António Carlos Silva / Pierluigi Rosina / Hugo Gomes / Anabela Borralheiro Pereira / George Nash / Esmeralda Gomes / Nelson Almeida / Carlos Carpetudo

523 Trabalhos de documentação de arte paleolítica realizados no âmbito do projeto PalæoCôa André Tomás Santos / António Fernando Barbosa / Luís Luís / Marcelo Silvestre / Thierry Aubry

537 Imagens fantasmagóricas, silhuetas elusivas: as figuras humanas na arte do Paleolítico Superior da região do Côa Mário Reis

$55^{1}$ Os motivos zoomórficos representados nas placas de tear de Vila Nova de São Pedro (Azambuja, Portugal) Andrea Martins / César Neves / José M. Arnaud / Mariana Diniz

571 Arte Rupestre do Monte de Góios (Lanhelas, Caminha). Síntese dos resultados dos trabalhos efectuados em 2007-2009 Mário Varela Gomes

599 Gravuras rupestres de barquiformes no Monte de S. Romão, Guimarães, Noroeste de Portugal Daniela Cardoso

613 Círculos segmentados gravados na Bacia do Rio Lima (Noroeste de Portugal): contributos para o seu estudo Diogo Marinho / Ana M.S. Bettencourt / Hugo Aluai Sampaio

631 Equídeos gravados no curso inferior do Rio Mouro, Monção (NW Portugal). Análise preliminar Coutinho, L.M. / Bettencourt, A.M.S / Sampaio, Hugo A.S

645 Paletas na Arte Rupestre do Noroeste de Portugal. Inventário preliminar Bruna Sousa Afonso / Ana M. S. Bettencourt / Hugo A. Sampaio 


\section{Pré-História}

661 O projeto Miño/Minho: balanço de quatro anos de trabalhos arqueológicos Sérgio Monteiro-Rodrigues / João Pedro Cunha-Ribeiro / Eduardo Méndez-Quintas / Carlos Ferreira / Pedro Xavier / José Meireles / Alberto Gomes / Manuel Santonja / Alfredo Pérez-González

677 A ocupação paleolítica da margem esquerda do Baixo Minho: a indústria lítica do sítio de Pedreiras 2 (Monção, Portugal) e a sua integração no contexto regional Carlos Ferreira / João Pedro Cunha-Ribeiro / Sérgio Monteiro-Rodrigues / Eduardo Méndez-Quintas / Pedro Xavier / José Meireles / Alberto Gomes / Manuel Santonja / Alfredo Pérez-González

693 O sítio acheulense do Plistocénico médio da Gruta da Aroeira Joan Daura / Montserrat Sanz / Filipa Rodrigues / Pedro Souto / João Zilhão

703 As sociedades neandertais no Barlavento algarvio: modelos preditivos com recurso aos SIG

Daniela Maio

715 A utilização de quartzo durante o Paleolítico Superior no território dos vales dos rios Vouga e Côa

Cristina Gameiro / Thierry Aubry / Bárbara Costa / Sérgio Gomes / Luís Luís / Carmen Manzano / André Tomás Santos

733 Uma perspetiva diacrónica da ocupação do concheiro do Cabeço da Amoreira (Muge, Portugal) a partir da tecnologia lítica Joana Belmiro / João Cascalheira / Célia Gonçalves

745 Novos dados sobre a Pré-história Antiga no concelho de Palmela. A intervenção arqueológica no sítio do Poceirão I

Michelle Teixeira Santos

757 Problemas em torno de Datas Absolutas Pré-Históricas no Norte do Alentejo Jorge de Oliveira

771 Povoamento pré-histórico nas áreas montanhosas do NO de Portugal: o Abrigo 1 de Vale de Cerdeira Pedro Xavier / José Meireles / Carlos Alves

783 Apreciação do povoamento do Neolítico Inicial na Baixa Bacia do Douro. A Lavra I (Serra da Aboboreira) como caso de estudo Maria de Jesus Sanches

797 O Processo de Neolitização na Plataforma do Mondego: os dados do Sector C do Outeiro dos Castelos de Beijós (Carregal do Sal)

João Carlos de Senna-Martinez / José Manuel Quintã Ventura / Andreia Carvalho / Cíntia Maurício

823 Novos trabalhos na Lapa da Bugalheira (Almonda, Torres Novas) Filipa Rodrigues / Pedro Souto / Artur Ferreira / Alexandre Varanda / Luís Gomes / Helena Gomes / João Zilhão

837 A pedra polida e afeiçoada do sítio do Neolítico médio da Moita do Ourives (Benavente, Portugal)

César Neves

857 Casal do Outeiro (Encarnação, Mafra): novos contributos para o conhecimento do povoamento do Neolítico final na Península de Lisboa.

Cátia Delicado / Carlos Maneira e Costa / Marta Miranda / Ana Catarina Sousa

873 Stresse infantil, morbilidade e mortalidade no sítio arqueológico do Neolítico Final/ Calcolítico ( $4^{\circ}$ e $3^{\circ}$ milénio a.C.) do Monte do Carrascal 2 (Ferreira do Alentejo, Beja) Liliana Matias de Carvalho / Sofia N. Wasterlain 
885 Come together: O Conjunto Megalítico das Motas (Monção, Viana do Castelo) e as expressões Campaniformes do Alto Minho Ana Catarina Basílio / Rui Ramos

899 Trabalhos arqueológicos no sítio Calcolítico da Pedreira do Poio Carla Magalhães / João Muralha / Mário Reis / António Batarda Fernandes

913 O sítio arqueológico de Castanheiro do Vento. Da arquitectura do sítio à arquitectura de um território João Muralha Cardoso

925 Estudo zooarqueológico das faunas do Calcolítico final de Vila Nova de São Pedro (Azambuja, Portugal): Campanhas de 2017 e 2018 Cleia Detry / Ana Catarina Francisco / Mariana Diniz / Andrea Martins / César Neves / José Morais Arnaud

943 As faunas depositadas no Museu Arqueológico do Carmo provenientes de Vila Nova de São Pedro (Azambuja): as campanhas de 1937 a 1967 Ana Catarina Francisco / Cleia Detry / César Neves / Andrea Martins / Mariana Diniz / José Morais Arnaud

959 Análise funcional de material lítico em sílex do castro de Vila Nova de S. Pedro (Azambuja, Portugal): uma primeira abordagem Rafael Lima

971 O recinto da Folha do Ouro 1 (Serpa) no contexto dos recintos de fossos calcolíticos alentejanos

António Carlos Valera / Tiago do Pereiro / Pedro Valério / António M. Monge Soares

\section{Proto-História}

987 Produção de sal marinho na Idade do Bronze do noroeste Português. Alguns dados para uma reflexão

Ana M. S. Bettencourt / Sara Luz / Nuno Oliveira / Pedro P. Simões / Maria Isabel C. Alves / Emílio Abad-Vidal

1001 A estátua-menir do Pedrão ou de São Bartolomeu do Mar (Esposende, noroeste de Portugal) no contexto arqueológico da fachada costeira de entre os rios Neiva e Cávado Ana M. S. Bettencourt / Manuel Santos-Estévez / Pedro Pimenta Simões / Luís Gonçalves

1015 O Castro do Muro (Vandoma/Baltar, Paredes) - notas para uma biografia de ocupação da Idade do Bronze à Idade Média

Maria Antónia D. Silva / Ana M. S. Bettencourt / António Manuel S. P. Silva / Natália Félix

1031 Do Bronze Final à Idade Média - continuidades e hiatos na ocupação de Povoados em Oliveira de Azeméis João Tiago Tavares / Adriaan de Man

1041 As faunas do final da Idade do Bronze no Sul de Portugal: leituras desde o Outeiro do Circo (Beja)

Nelson J. Almeida / Íris Dias / Cleia Detry / Eduardo Porfírio / Miguel Serra

1055 A Espada do Monte das Oliveiras (Serpa) - uma arma do Bronze Pleno do Sudoeste Rui M. G. Monge Soares / Pedro Valério / Mariana Nabais / António M. Monge Soares

1065 São Julião da Branca (Albergaria-a-Velha) - Investigação e valorização de um povoado do Bronze Final

António Manuel S. P. Silva / Paulo A. P. Lemos / Sara Almeida e Silva / Edite Martins de Sá

1083 Do castro de S. João ao Mosteiro de Santa Clara: notícia de uma intervenção arqueológica, em Vila do Conde Rui Pinheiro 
1095 O castro de Ovil (Espinho), um quarto de século de investigação - resultados e questões em aberto

Jorge Fernando Salvador / António Manuel S. P. Silva

1111 O Castro de Salreu (Estarreja), um povoado proto-histórico no litoral do Entre Douro e Vouga

Sara Almeida e Silva / António Manuel S. P. Silva / Paulo A. P. Lemos / Edite Martins de Sá

1127 Castro de Nossa Senhora das Necessidades (Sernancelhe): uma primeira análise artefactual Telma Susana O. Ribeiro

${ }_{1141}$ A cividade de Bagunte. O estado atual da investigação Pedro Brochado de Almeida

1153 Zoomorfos na cerâmica da Idade do Ferro no NW Peninsular: inventário, cronologias e significado Nuno Oliveira / Cristina Seoane

1163 Vasos gregos em Portugal: diferentes maneiras de contar a história do intercâmbio cultural na Idade do Ferro

Daniela Ferreira

1175 Os exotica da necrópole da Idade do Ferro do Olival do Senhor dos Mártires (Alcácer do Sal) no seu contexto regional

Francisco B. Gomes

\section{Antiguidade Clássica e Tardia}

1191 O uso de madeira como combustível no sítio da Quinta de Crestelos (Baixo Sabor): da Idade do Ferro à Romanização Filipe Vaz / João Tereso / Sérgio Simões Pereira / José Sastre / Javier Larrazabal Galarza / Susana Cosme / José António Pereira / Israel Espi

1207 Cultivos de Época Romana no Baixo Sabor: continuidade em tempos de mudança? João Pedro Tereso / Sérgio Simões Pereira / Filipe Santos / Luís Seabra / Filipe Vaz

1221 A casa romana na Hispânia: aplicação dos modelos itálicos nas províncias ibéricas Fernanda Magalhães / Diego Machado / Manuela Martins

1235 As pinturas murais romanas da Rua General Sousa Machado, n. ${ }^{5}$ 1, Chaves José Carvalho

1243 Trás do Castelo (Vale de Mir, Pegarinhos, Alijó) - Uma exploração agrícola romana do Douro

Tony Silvino / Pedro Pereira

1255 A sequência de ocupação no quadrante sudeste de Bracara Augusta: as transformações de uma unidade doméstica Lara Fernandes / Manuela Martins

1263 Os Mosaicos com decoração geométrica e geométrico-vegetalista dos sítios arqueológicos da área do Conuentus Bracaraugustanus. Novas abordagens quanto à conservação, restauro, decoração e datação Maria de Fátima Abraços / Licínia Wrench

1277 “Casa Romana” do Castro de São Domingos (Cristelos, Lousada): Escavação, Estudo e Musealização Paulo André de P. Lemos

1291 A arqueobotânica no Castro de Guifões (Matosinhos, Noroeste de Portugal): O primeiro estudo carpológico

Luís Seabra / Andreia Arezes / Catarina Magalhães / José Varela / João Pedro Tereso 
1305 Um Horreum Augustano na Foz do Douro (Monte do Castelo de Gaia, Vila Nova de Gaia) Rui Ramos

1311 Ponderais romanos na Lusitânia: padrões, formas, materiais e contextos de utilização Diego Barrios Rodríguez

1323 Um almofariz centro-itálico na foz do Mondego

Marco Penajoia

1335 Estruturas romanas de Carnide - Lisboa Luísa Batalha / Mário Monteiro / Guilherme Cardoso

1347 O contexto funerário do sector da "necrópole NO" da Rua das Portas de S. Antão (Lisboa): o espaço, os artefactos, os indivíduos e a sua interconectividade na interpretação do passado Sílvia Loja, José Carlos Quaresma, Nelson Cabaço, Marina Lourenço, Sílvia Casimiro, Rodrigo Banha da Silva, Francisca Alves-Cardoso

${ }_{1361}$ Povoamento em época Romana na Amadora - resultados de um projeto pluridisciplinar Gisela Encarnação / Vanessa Dias

1371 A Arquitectura Residencial em Mirobriga (Santiago do Cacém): contributo a partir de um estudo de caso Filipe Sousa / Catarina Felício

${ }_{1385}$ O fim do ciclo. Saneamento e gestão de resíduos nos edifícios termais de Mirobriga (Santiago do Cacém)

Catarina Felício / Filipe Sousa

1399 Balsa, Topografia e Urbanismo de uma Cidade Portuária Vítor Silva Dias / João Pedro Bernardes / Celso Candeias / Cristina Tété Garcia

1413 No Largo das Mouras Velhas em Faro (2017): novas evidências da necrópole norte de Ossonoba e da sua ocupação medieval Ricardo Costeira da Silva / Paulo Botelho / Fernando Santos / Liliana Nunes

1429 Instrumentos de pesca recuperados numa fábrica de salga em Ossonoba (Faro) Inês Rasteiro / Ricardo Costeira da Silva / Paulo Botelho

1439 A Necrópole Romana do Eirô, Duas Igrejas (Penafiel): intervenção arqueológica de 2016 Laura Sousa / Teresa Soeiro

1457 Ritual, descarte ou afetividade? A presença de Canis lupus familiaris na Necrópole Noroeste de Olisipo (Lisboa)

Beatriz Calapez Santos / Sofia Simões Pereira / Rodrigo Banha da Silva / Sílvia Casimiro / Cleia Detry / Francisca Alves Cardoso

1467 Dinâmicas económicas em Bracara na Antiguidade Tardia Diego Machado / Manuela Martins / Fernanda Magalhães / Natália Botica

1479 Cerâmicas e Vidros da Antiguidade Tardia do Edifício sob a Igreja do Bom Jesus (Vila Nova de Gaia) Joaquim Filipe Ramos

1493 Novos contributos para a topografia histórica de Mértola no período romano e na Antiguidade Tardia Virgílio Lopes

\section{8. Época Medieval}

1511 Cerâmicas islâmicas no Garb setentrional "português": algumas evidências e incógnitas Constança dos Santos / Helena Catarino / Susana Gómez / Maria José Gonçalves / Isabel Inácio / Gonçalo Lopes / Jacinta Bugalhão / Sandra Cavaco / Jaquelina Covaneiro / Isabel Cristina Fernandes / Ana Sofia Gomes 
1525 Contributo para o conhecimento da cosmética islâmica, em Silves, durante a Idade Média Rosa Varela Gomes

1537 Yábura e o seu território - uma análise histórico-arqueológica de Évora entre os séculos VIII-XII José Rui Santos

1547 A encosta sul do Castelo de Palmela - resultados preliminares da escavação arqueológica Luís Filipe Pereira / Michelle Teixeira Santos

1559 A igreja de São Lourenço (Mouraria, Lisboa): um conjunto de silos e de cerâmica medieval islâmica

Andreia Filipa Moreira Rodrigues

1571 O registo material de movimentações populacionais no Médio Tejo, durante os séculos XII-XIII. Dois casos de "sunken featured buildings", nos concelhos de Cartaxo e Torres Novas Marco Liberato / Helena Santos / Nuno Santos

1585 O nordeste transmontano nos alvores da Idade média. Notas para reflexão Ana Maria da Costa Oliveira

1601 Sepulturas escavadas na rocha do Norte de Portugal e do Vale do Douro: primeiros resultados do Projecto SER-NPVD

Mário Jorge Barroca / César Guedes / Andreia Arezes / Ana Maria Oliveira

1619 "Portucalem Castrum Novum" entre o Mediterrâneo e o Atlântico: o estudo dos materiais cerâmicos alto-medievais do arqueossítio da rua de D. Hugo, nํ. 5 (Porto) João Luís Veloso

1627 A Alta Idade Média na fronteira de Lafões: notas preliminares sobre a Arqueologia no Concelho de Vouzela

Manuel Luís Real / Catarina Tente

1641 Um conjunto cerâmico medieval fora de portas: um breve testemunho aveirense Susana Temudo

${ }_{1651}$ Os Lóios do Porto: uma perspetiva integrada no panorama funerário da Baixa Idade Média à Época Moderna em meios urbanos em Portugal

Ana Lema Seabra

1659 O Caminho Português Interior de Santiago como eixo viário na Idade Média Pedro Azevedo

1665 Morfologia Urbana: Um exercício em torno do Castelo de Ourém André Donas-Botto / Jaqueline Pereira

1677 Intervenção arqueológica na Rua Marquês de Pombal/Largo do Espírito Santo (Bucelas, Loures)

Florbela Estêvão / Nathalie Antunes-Ferreira / Dário Ramos Neves / Inês Lisboa

1691 O Cemitério Medieval do Poço do Borratém e a espacialidade funerária na cidade de Lisboa Inês Belém / Vanessa Filipe / Vasco Noronha Vieira / Sónia Ferro / Rodrigo Banha da Silva

1705 Um Espaço Funerário Conventual do séc. XV em Lisboa: o caso do Convento de São Domingos da Cidade Sérgio Pedroso / Sílvia Casimiro / Rodrigo Banha da Silva / Francisca Alves Cardoso

\section{9. Época Moderna e Contemporânea}

1721 Arqueologia Moderna em Portugal: algumas reflexões críticas em torno da quantificação de conjuntos cerâmicos e suas inferências históricas e antropológicas Rodrigo Banha da Silva / André Bargão / Sara da Cruz Ferreira

1733 Faianças de dois contextos entre os finais do século XVI e XVIII do Palácio dos Condes de Penafiel, Lisboa

Martim Lopes / Tomás Mesquita 
1747 Um perfil de consumo do século XVIII na foz do Tejo: O caso do Mercado da Ribeira, Lisboa Sara da Cruz Ferreira / Rodrigo Banha da Silva / André Bargão

1761 Os Cachimbos dos Séculos XVII e XVIII do Palácio Mesquitela e Convento dos Inglesinhos (Lisboa)

Inês Simão / Marina Pinto / João Pimenta / Sara da Cruz Ferreira / André Bargão / Rodrigo Banha da Silva

1775 "Tomar os fumos da erua que chamão em Portugal erua sancta». Estudo de Cachimbos provenientes da Rua do Terreiro do Trigo, Lisboa

Miguel Martins de Sousa / José Pedro Henriques / Vanessa Galiza Filipe

1787 Cachimbos de Barro Caulínitico da Sé da Cidade Velha (República de Cabo Verde)

Rodrigo Banha da Silva / João Pimenta / Clementino Amaro

1801 Algumas considerações sobre espólio não cerâmico recuperado no Largo de Jesus (Lisboa) Carlos Boavida

1815 Adereços de vidro, dos séculos XVI-XVIII, procedentes do antigo Convento de Santana de Lisboa (anéis, braceletes e contas)

Joana Gonçalves / Rosa Varela Gomes / Mário Varela Gomes

1837 Da ostentação, luxo e poder à simplicidade do uso quotidiano: arqueologia e simbologia de joias e adornos da Idade Moderna Portuguesa Jéssica Iglésias

1849 Os amuletos em Portugal - dos objetos às superstições: o coral vermelho Alexandra Vieira

1865 Cerâmicas de Vila Franca de Xira nos séculos XV e XVI Eva Pires

1879 «Não passa por teu o que me pertence». Marcas de individualização associadas a faianças do Convento de Nossa Senhora de Aracoeli, Alcácer do Sal Catarina Parreira / Íris Fragoso / Miguel Martins de Sousa

1891 Cerâmica de Leiria: alguns focos de produção

Jaqueline Pereira / André Donas-Botto

1901 Os Fornos na Rua da Biquinha, em Óbidos Hugo Silva / Filipe Oliveira

1909 A casa de Pêro Fernandes, contador dos contos de D. Manuel I: o sítio arqueológico da Silha do Alferes, Seixal (século XVI) Mariana Nunes Ferreira

1921 O Alto da Vigia (Sintra) e a vigilância e defesa da costa Alexandre Gonçalves / Sandra Santos

1937 O contexto da torre sineira da Igreja de Santa Maria de Loures Paulo Calaveira / Martim Lopes

1949 A Necrópole do Hospital Militar do Castelo de São Jorge e as práticas funerárias na Lisboa de Época Moderna Susana Henriques / Liliana Matias de Carvalho / Ana Amarante / Sofia N. Wasterlain

1963 SAND - Sarilhos Grandes Entre dois Mundos: o adro da Igreja e a Paleobiologia dos ossos humanos recuperados

Paula Alves Pereira / Roger Lee Jesus / Bruno M. Magalhães

1975 Expansão urbana da vila de Cascais no século XVII e XVIII: a intervenção arqueológica na Rua da Vitória no 15 a 17

Tiago Pereira / Vanessa Filipe

1987 Novos dados para o conhecimento do Urbanismo de Faro em época Moderna Ana Rosa 
1995 Um exemplo de Arqueologia Urbana em Alcoutim: o Antigo Edifício dos CTT Marco Fernandes / Marta Dias / Alexandra Gradim / Virgílio Lopes / Susana Gómez Martínez

2007 Palácio dos Ferrazes (Rua das Flores/Rua da Vitória, Porto): a cocheira de Domingos Oliveira Maia

Francisco Raimundo

2021 As muitas vidas de um edifício urbano: História, Arqueologia e Antropologia no antigo Recreatório Paroquial de Penafiel Helena Bernardo / Jorge Sampaio / Marta Borges

2035 O convento de Nossa Senhora da Esperança de Ponta Delgada: o contributo da arqueologia para o conhecimento de um monumento identitário João Gonçalves Araújo / N’Zinga Oliveira

2047 Arqueologia na ilha do Corvo... em busca da capela de Nossa Senhora do Rosário Tânia Manuel Casimiro / José Luís Neto / Luís Borges / Pedro Parreira

2059 Perdidos à vista da Costa. Trabalhos arqueológicos subaquáticos na Barra do Tejo Jorge Freire / José Bettencourt / Augusto Salgado

2071 Arqueologia marítima em Cabo Verde: enquadramento e primeiros resultados do projecto CONCHA

José Bettencourt / Adilson Dias / Carlos Lima / Christelle Chouzenoux / Cristóvão Fonseca / Dúnia Pereira / Gonçalo Lopes / Inês Coelho / Jaylson Monteiro / José Lima / Maria Eugénia Alves / Patrícia Carvalho / Tiago Silva

2085 Trabalhos arqueológicos na Cidade Velha (Ribeira Grande de Santiago, Cabo Verde): reflexões sobre um projecto de investigação e divulgação patrimonial André Teixeira / Jaylson Monteiro / Mariana Mateus / Nireide Tavares / Cristovão Fonseca / Gonçalo C. Lopes / Joana Bento Torres / Dúnia Pereira / André Bargão / Aurélie Mayer / Bruno Zélie / Carlos Lima / Christelle Chouzenoux / Inês Henriques / Inês Pinto Coelho / José Lima / Patrícia Carvalho / Tiago Silva

2103 A antiga fortificação de Quelba / Khor Kalba (E.A.U.). Resultados de quatro campanhas de escavações, problemáticas e perspectivas futuras Rui Carita / Rosa Varela Gomes / Mário Varela Gomes / Kamyar Kamyad

2123 Colónias para homens novos: arqueologia da colonização agrária fascista no noroeste ibérico Xurxo Ayán Vila / José Mạ . Señorán Martín 


\title{
DINÂMICAS ECONÓMICAS EM BRACARA NA ANTIGUIDADE TARDIA
}

\author{
Diego Machado ${ }^{1}$, Manuela Martins ${ }^{2}$, Fernanda Magalhães ${ }^{3}$, Natália Botica ${ }^{4}$
}

\begin{abstract}
RESUMO
O estudo do período histórico que sucedeu ao Império Romano no Ocidente evidenciou profundas transformações sociais e económicas que tiveram grande expressão no tecido urbano das cidades. Neste sentido, propomos uma síntese sobre as dinâmicas económicas de Bracara na Antiguidade Tardia, período profundamente marcado, por um lado, pela afirmação de novas realidades urbanísticas, sociais, políticas e religiosas, e por outro, pelo gradativo abandono de condicionantes e imperativos que marcaram a cidade alto-imperial. Para tal, vamos recorrer aos dados provenientes das intervenções arqueológicas realizadas em Braga, que documentam as transformações ocorridas entre os séculos III e VIII, período balizado pela elevação da cidade à capital da Gallaecia e pelas invasões muçulmanas, que marcam o fim do comércio a nível mediterrânico.
\end{abstract}

Palavras-chave: Bracara, Antiguidade Tardia, Economia, Sociedade.

\begin{abstract}
The study of the historical period that followed the Western Roman Empire evidenced social and economic transformations that had great expression in the urban fabric of cities. In this sense, we propose a synthesis of the economic dynamics of Bracara in Late Antiquity, a period marked by the affirmation of new urban, social, political and religious realities, as well as by the gradual abandonment of constraints and imperatives that marked the previous city. For that, we will use data from archaeological interventions carried out in Braga, which document how transformations occurred between $3^{\text {rd }}-8^{\text {th }}$ centuries, a period delimited by the elevation of the city to capital of Gallaecia and Muslim invasions, which mark the end of trade at Mediterranean level.

Keywords: Bracara, Late Antiquity, Economy, Society.
\end{abstract}

\section{INTRODUÇÃO}

Após um período de grande desenvolvimento económico e cultural que conformou um pujante Império desde Augustus até a dinastia Nerva-Antonina, com a morte de Commodus, em 193, foi iniciado um período de bastante instabilidade política que apenas se viu apaziguada no final daquele ano com a ascensão de Septimius Seuerus. Contudo, os quarenta e três anos que a dinastia dos Severos esteve com o comando de Roma foram marcados por constantes entraves bélicos nos limites do Império que, apesar de terem garantido o controlo sobre os vastos territórios, terminaram por agravar a instabilidade que antecedeu aos Seuerii e resultou num período de grande crise política e económica, marcado por sucessivas usurpações do poder imperial e uma profunda desvalorização da moeda romana, que só vai ser recuperado com a ascensão de Diocletianus, em 284 (De Blois, 2019).

Porém, a crise do século III afetou, de facto, a Península Itálica, com particular destaque para Roma e as cidades cuja economia estava centrada na produção monocultural voltada ao abastecimento da capital do Império, levando a um quadro de diminuição do índice de importação, em comparação com aquele que havia nos séculos anteriores. Na Hispânia, e em especial no noroeste da Península Ibérica, esta crise

\footnotetext{
1. Unidade de Arqueologia da Universidade do Minho, Lab2PT, UMinho; diegosfmachado@gmail.com.

2. Unidade de Arqueologia da Universidade do Minho, Lab2PT, UMinho; mmmartins@uaum.uminho.pt.

3. Unidade de Arqueologia da Universidade do Minho, Lab2PT, UMinho; fmagalhaes@uaum.uminho.pt.

4. Unidade de Arqueologia da Universidade do Minho, Lab2PT, UMinho; nb@uaum.uminho.pt.
} 
não parece ter sido tão significativa, uma vez que os vestígios arqueológicos documentam um período marcado, sobretudo, por um quadro de continuidade a nível das estruturas e dos materiais, apesar da rarefação do numerário em circulação, sobretudo aquele constituído por moedas de maior qualidade (Ripollès Alegre, 2002; Ruivo, 2008; Vila Franco, 2012). Em Bracara, por sua vez, a promoção da cidade a capital da província da Gallaecia, criada por Diocletianus, nos finais do século III, intensificou a competição pelos altos cargos na administração provincial e proporcionou a emergência de uma sociedade ainda mais hierarquizada e economicamente dinâmica.

Entretanto, a desarticulação política e administrativa romana nas antigas províncias ocidentais, que na Hispania aconteceu logo nos inícios do século V, deu origem a novos poderes e relações, associados com a instalação dos povos germânicos, sem que isso, contudo, significasse a total dissolução das tradicionais rotas de intercâmbio, que permaneceram em funcionamento até à invasão muçulmana, nos finais do século VII, no norte da África, importante parceiro comercial do Ocidente europeu, e nos inícios do século VIII na Hispânia (Pirenne, 1925). No plano social, por sua vez, as relações globais que o Império proporcionava não sobreviveram ao colapso da estrutura administrativa nas províncias ocidentais, ainda que as estruturas organizativas não tenham sofrido alterações significativas, apesar da transferência do poder que antes vinha do Imperador em Roma e que passou a ser detido pelo bispo na basílica (Brown, 1971).

Assim, realizaremos uma síntese das dinâmicas económicas de Bracara durante a Antiguidade Tardia, de modo a melhor evidenciar os processos que incidiram sobre a cidade com o fim do Principado até ao século VIII. Esta abordagem irá privilegiar a análise dos dados arqueológicos de Braga, com enfoque na atividade construtiva, na produção oleira e vítrea, na circulação monetária e nas importações.

\section{A ATIVIDADE CONSTRUTIVA}

Bracara é herdeira do processo evolutivo que Bracara Augusta teve desde a sua fundação, em finais do século I a.C., até à consolidação dos processos construtivos que conformaram uma cidade de significativas dimensões e detentora de um alargado conjunto de equipamentos públicos, urbanísticos e habitacionais. Com efeito, as primeiras décadas que sucederam à fundação da cidade foram marcadas pela implantação de estruturas públicas fundamentais ao funcionamento do centro urbano, representadas pelo forum, onde se teriam construído os edifícios religiosos e judiciais, mas também pelos equipamentos urbanos viários e pelas infraestruturas de abastecimento de água e drenagem de resíduos, dando origem a uma malha urbana bastante homogénea, formada por quarteirões quadrados com dimensão de 1 actus e uma área total de cerca de zoha (Martins \&alii, 2017a).

Uma vez que a estrutura urbana estava criada, foi iniciada a ocupação do parque habitacional da cidade, em época flávia, que estava representado por domus que preenchiam a metade ou a totalidade dos quarteirões rodeados por eixos pedonais porticados e reproduziam com grande qualidade o léxico arquitetónico itálico nas plantas e na escolha dos materiais (Magalhães, 2019). Durante a dinastia nerva-antonina foram implantados equipamentos públicos ligados ao ócio e entretenimento, como as termas públicas do Alto da Cividade e da rua Afonso Henriques, um teatro e um anfiteatro (Morais, 2001; Martins et al., 2015; 2017b).

Por sua vez, nos dois últimos séculos da administração romana em Bracara, e a partir dos finais do século III com a promoção da cidade a capital da província da Gallaecia, os investimentos construtivos passam a tomar outros rumos. Embora ainda tenham sido mantidas atividades construtivas públicas, como a reforma nas termas públicas do Alto da Cividade, cujo abandono aconteceu somente nos inícios do século V (Martins, 2005), e, especialmente, a construção de uma muralha que cercou uma área de 48 ha, mais ampla que a cidade planificada (Lemos, Leite \& Cunha, 2007), é a nível do contexto doméstico que as maiores transformações desse período foram documentadas.

Com efeito, os investimentos realizados nas domus da cidade entre os séculos III e IV foram deveras significativos e refletem a busca pela ascensão política e social das elites bracarenses face às novas possibilidades de cargos na administração pública provincial (Figura 1).

Algumas antigas habitações que ocupavam metade de quarteirões foram expandidas para o lote contíguo através da compra do mesmo pelo proprietário, como está documentado na domus da Rua Frei Caetano Brandão/Escola Velha da Sé, o que permitiu a reprodução de salas de representação para a receção 
de conuiuas, atividades expectáveis de qualquer $p a-$ terfamilias que busca ampliar as suas relações com os demais membros da elite urbana. Assim como, e de maneira bastante generalizada pelas habitações da cidade, os programas decorativos dos espaços domésticos com uso público passaram por reformas que incluíam o uso de mosaicos para cobrir os pavimentos e de pinturas para as paredes e o mármore, utilizado em capitéis e outros elementos arquitetónicos. Este processo está bem documentado na domus das Antigas Cavalariças de Braga, onde foram recuperados restos de tesselae desses mosaicos e identificado um ninfeu com pavimento em opus alexandrino, bem como a construção de espaços termais destinados ora ao uso privado e ora ao público, como da domus da Escola Velha da Sé e Frei Caetano Brandão e da domus das Carvalheiras (Ribeiro, 2010; Magalhães, 2010; 2019).

Por outro lado, foi identificado um fenómeno de apropriação do espaço público pelos proprietários de algumas habitações de modo a ampliarem as suas residências através da ocupação dos antigos eixos pedonais porticados. Essa alteração deu-se através do avanço do espaço doméstico sobre as tabernae que se dispunham ao longo das fachadas das casas, abertas ao pórtico que delimitava o quarteirão, e essas lojas, por sua vez, sobre o eixo porticado, resultando na completa alteração da paisagem urbana que definia Bracara Augusta, bem marcada pelo ritmo das colunas ao redor das insulae (Magalhães, 2019). Da mesma forma, outro fenómeno identificado na cidade a partir do século IV, e que também rompe com a forma urbis da cidade planificada augustana, é a orientação de novas construções em relação à muralha e não à malha urbana, observando-se ainda o avanço de edifícios sobre algumas ruas que perderam a importância que tinham no período anterior (Pereira, 2018).

Se, por um lado, as reformas registadas nas domus bracarenses assinalam um período de grande investimento no património privado dos seus proprietários, por outro lado, os espaços públicos de entretenimento são abandonados e desmantelados. Com a desafetação do teatro de Bracara Augusta, entre os séculos III-IV, as suas estruturas foram, gradativamente, reutilizadas para a criação de novos contextos construtivos residenciais e artesanais. Com efeito, a área a norte do parascaenium foi remodelada e nela implantada uma unidade habitacional, enquanto o muro perimetral, na plataforma superior, foi reutilizado como parede de uma construção de carácter artesanal, bem marcada pela identificação de um forno destinado ao derretimento do bronze e ainda, num espaço um pouco mais a norte, foi construída uma outra estrutura, que reutilizou a parte da parede do aqueduto que cruza aquela área, com um ramal que assegurava o abastecimento das termas. Ao nível das técnicas construtivas dessas novas habitações é importante salientar que abandonam completamente o utilizado na restante da cidade, onde o uso do granito é generalizado. Essas estruturas utilizam placas de xisto na base dos muros, alçados em madeira e os pavimentos eram em terra batida (Martins \& alii, 2015).

Com o fim da administração romana e a instalação dos suevos na Gallaecia assistimos a um processo de profundas modificações nos contextos privados bracarenses. Se os últimos séculos da ocupação romana foram marcados pelo aprofundamento do léxico arquitetónico itálico nas habitações com a ampliação dos espaços de representação e dos programas decorativos, os séculos V-VII são marcados pelo colapso das grandes casas de elite unifamiliares através do desmembramento dos antigos compartimentos para criação de novas realidades habitacionais mais pequenas que recortam as plantas das domus. Esse fenómeno, ainda que mal conhecido devido ao caráter fragmentário das escavações em Braga e da má preservação dos vestígios, encontra-se reconhecido em alguns zonas arqueológicas da cidade, como a do Ex-Albergue Distrital e das Cavalariças (Martins $\&$ alii, 2016).

\section{PRODUÇÃO OLEIRA E VÍTREA}

Desde as primeiras décadas a cidade fabricou recipientes cerâmicos e vítreos cujas diferentes produções atendiam à diversificada população que nela habitava. Com efeito, no que toca às atividades oleiras, ao longo do século I foram manufaturados objetos que apresentavam uma continuidade formal e tecnológica em relação às produções da Idade do Ferro, as chamadas cerâmicas de tradição indígena, bem como outras que assinalam variações a nível das pastas, mas que ainda são enquadrados como produtos comuns, sem grande acabamento ou decoração, que seria destinado ao uso de cozinha ou que compunham as mesas das classes menos afortunadas. Por outro lado, também foram produzidos recipientes em que se observa um maior cuidado no 
que toca ao alisamento das paredes ou à aplicação de pinturas, com fim decorativo, ou engobes, para revestimento das superfícies. Neste grupo estão representadas as cerâmicas comum fina, fina pintada, cinzenta fina polida e engobe vermelho (Delgado \& Morais, 2009).

Não obstante, outras produções locais dos primeiros séculos da cidade especializaram-se na reprodução de formas exógenas em recipientes de alta qualidade, certamente destinados a uma camada da população com melhores condições financeiras e ao mercado regional, identificadas tanto no conuentus bracaraugustano como no lucense. Estão representados nesse grupo os fabricos de cerâmica bracarense, que imita as terrae sigillatae hispânicas, as paredes finas, cujo paralelo são as produções de mesmo nome originárias da Bética, bem como alguns objetos em manufaturas já mencionadas como as finas pintadas e os engobes vermelhos (Leite, 1997; Gomes, 2000; Delgado \& Morais, 2009).

Por sua vez, o início da Antiguidade Tardia marcou uma clara evolução no seio da produção oleira bracarense. Com efeito, as produções comuns finas e pintadas assumem formas específicas a partir do século IV, em que se destaca a imitação de Hisp. 56 entre as primeiras e o uso das cores branco e vermelho nas decorações das outras. Por sua vez, as cerâmicas de engobe vermelho assumem caraterísticas tecnológicas bastante distintas, principalmente a nível da tonalidade do acabamento e começam a imitar peças originalmente em terra sigillata africana e hispânica tardia, sobretudo no que toca aos pratos e cassarolas (Delgado, 1993-94; Delgado \& Morais, 2009).

Da mesma forma, outros fabricos começam a ser produzidos nesse período, designadamente as cerâmicas de engobe branco, cinzentas tardias e as vidradas (Figura 2). As primeiras possuem como caraterística principal o acabamento que recebem com um engobe cuja manufatura foi iniciada nos finais do século III mas conheceu maior presença em contextos do século $\mathrm{V}$ em formas como os jarros e os potes, por vezes com decorações vegetalistas ou geométricas (Delgado \& Morais, 2009).

As chamadas cinzentas tardias são dividas em duas categorias, comuns e de imitação. O primeiro grupo é caraterizado pelo fabrico de recipientes entre os finais do século IV e o VII que não apresentam grande cuidado a nível dos acabamentos, bem como pelas paredes espessas e formas tradicionalmente associadas a um uso na cozinha, como potes, tige- las e bilhas, embora algumas estejam vinculadas a funções de mesa e despensa. Por outro lado, as cerâmicas cinzentas tardias de imitação, presentes em contextos dos séculos V e VI, reproduzem uma ampla gama de objetos originalmente em terra sigillata africana, focense e gálica e apresentam um significativo esforço técnico no que toca à depuração das pastas e ao tratamento das superfícies, sempre bastante polidas (Gaspar, 2000).

Por fim, outra produção bastante particular do período tardio bracarense está representada pelos fabricos de almofarizes em cerâmica comum grosseira que recebem no interior um caraterístico vidrado plumbífero (Figura 3), estando presente em contextos de finais do século IV e a sétima centúria (Delgado \& Morais, 2009; Martínez Peñín \& alii, 2018).

No que toca à produção vítrea, reconhece-se que a mesma tenha sido iniciada ainda no século I, tendo sido identificado na zona arqueológica do quarteirão dos CTT vestígios de uma fábrica que teria funcionado entre a primeira e a segunda centúria (Cruz, 2009, pp. 217-219; Martins \& alii, 2009). Nesse período, as formas presentes no registo arqueológico são aquelas que, de certo modo, atestam uma homogeneidade do Império Romano, bem marcado pelas taças caneladas e garrafas quadrangulares em vidro verde azulado, taças helenísticas e vidro de mosaico policromático, do século I, e o vidro incolor na centúria seguinte (Cruz, 2009, pp. 136-139).

Contudo, estão melhor estudados os locais de produção vítrea de época tardia, bem como os fabricos dessa época que assumem um caráter mais local ou regional. Com efeito, a já referida fábrica do quarteirão dos CTT apresenta uma segunda fase, cujo abandono aconteceu no século $\mathrm{V}$, onde foi possível registar um forno circular que apresenta a incorporação da tecnologia de fusão do vidro em cadinho e não em cuba, como acontecia com o forno da fase anterior (Figura 3) (Cruz, 2009, pp. 217-223).

Outro local de produção de vidro reconhecido em Bracara é aquele localizado na zona arqueológica da Quinta do Fujacal. Nesta parte da cidade foi identificada uma significativa concentração de restos de produção vidreira o que sugere a existência de uma verdadeira zona artesanal que congregaria várias oficinas, cujo funcionamento não teria ultrapassado o século VI (Cruz, 2009, p. 236).

No referente às produções tardias, é possível destacar três que, por um lado, são reconhecidamente bracarenses e, por outro, apresentam grande expres- 
são no registo arqueológico. A primeira trata-se das taças paleocristãs, bastante frequentes em contextos dos séculos IV e V, em cuja base recebem um símbolo cristão, seja a cruz ou o anagrama formado pelas letras gregas chi e ro.

Já a taça campanulada é aquela que mais abunda em Bracara no período tardio, sendo uma produção caraterizada pelo bordo em "cabeça de fósforo", perfil em forma de sino ou campânula e base reentrante com marca de pontel, cujas variantes vão dos recipientes amplos e baixos aos fundos. É uma produção que recorre sistematicamente à reciclagem de vidro e que apresenta grandes impurezas associadas às oficinas, apresentando-se numa variação cromática que vai do castanho amarelado ao verde amarelado (Cruz, 2009, pp. 74-77; 2011, pp. 87-88).

Por fim, temos uma produção de adornos em vidro negro opaco fabricados entre os séculos IV e V com uma variabilidade formal representada por braceletes, anéis, alfinetes, contas de colar, amuletos e falsas gemas, especialmente imitações de nicolos, uma variedade de ágata. Trata-se de uma produção realizada na zona artesanal do Fujacal onde foi identificado um amplo conjunto de restos de produção e cadinhos com vidro negro agarrado ao fundo (Cruz, 2008).

A produção oleira e vítrea bracarense tardia conhece uma expressão comercial deveras significativa. Além do abastecimento da cidade de Bracara, essas produções também estavam presentes no território do conuentus bracaraugustano e na área meridional do lucense, posteriormente reino Suevo, encontrando grande expressão entre os materiais importados no porto de Vigo e nas uillae da região, como a de Toralla (Fernández Fernández, 2013).

Dos objetos produzidos localmente e que abasteciam o mercado regional da zona ocidental do noroeste ibérico destacamos os recipientes em cerâmica vidrada, de engobe branco e de engobe vermelho, cuja forte expressão no registo arqueológico do Entre Douro e Minho e sul da Galiza, bem como em locais mais distantes como Conimbriga ou Troia, na Lusitannia, conduz alguns investigadores a classificar a segunda produção como Terra Sigillata Bracarense Tardia, sob a sigla TSBT. Estes materiais conheceram dois períodos de um forte intercâmbio durante os séculos IV e V, tendo o auge do primeiro ocorrido na segunda metade da primeira centúria e do segundo nos finais da última (Morais \& alii, 2014; Fernández Fernández; 2017; \& alii, 2019).

Por sua vez, a produção vítrea tardia bracarense também alcança grande expressão nos mercados regionais do noroeste da Península Ibérica. A dinâmica comercial desta região entre os séculos IV e V garantiu que os objetos produzidos em Bracara fossem difundidos pelo conuentus bracaraugustanus e mesmo fora dele, como documenta a identificação de taças paleocristãs em Coruxo (Pontevedra), Lugo e Clúnia, bem como uma conta e um pendente em vidro negro opaco proveniente da uilla de Toralla, Vigo (Cruz, 2009, pp. 274-276; Fernández Fernández, 2013).

\section{CIRCULAÇÃO MONETÁRIA}

Dentre os aspetos das dinâmicas económicas, talvez a circulação monetária seja o menos conhecido. Por um lado, isso deve-se ao menor número de estudos sobre os numismas encontrados em Bracara no período tardio, e por outro, ao baixo número de moedas identificadas na cidade cujo contexto encontra-se documentado, com exceção daquelas em bronze produzidas até a primeira metade do século $\mathrm{V}$.

Com efeito, existem até ao momento alguns estudos que tentaram compreender esses objetos no seio da sociedade bracarense desse período, e que, necessariamente, incidiram sobre conjuntos monetários constituídos pelos numerosos bronzes tardios exumados na cidade.

Desta feita, sabemos que o século III conheceu uma diminuição na massa monetária em circulação em Bracara, ainda que as suas cunhagens apresentassem um maior valor, expresso pela maior qualidade das ligas utilizadas (Zabaleta Estévez, 1999, pp. 82-83). Dada a instabilidade na provisão de moedas, recorrentemente foram utilizados numismas por períodos bastante extensos, como parece ter sido o caso das emissões antoninas, em uso ao longo da primeira metade do século III, e aqueles produzidos sob os signa dos imperadores Claudius II e Galienus (260-270) que se mantiveram em circulação até pelo menos 335 quando o abastecimento parece ter sido regularizado (Amaral, 2007).

O aprovisionamento de moedas para Bracara, e de toda a Península Ibérica, cujo objetivo incidia no pagamento de funcionários da administração conventual e provincial, era realizado com base nas casas de cunhagem localizadas em Roma, Lugdunum e Arelate (atuais Lyon e Arles, em França, respetivamente). A isso deve-se o elevado número de numismas identificados que foram produzidos em offici- 
nae proveniente destas cidades, cuja percentagem em comparação com o total de objetos ultrapassa os $50 \%$, bem como a significativa quantidade de ocultamentos monetários identificados em contextos habitacionais em cuja composição figuram moedas produzidas desde os finais do século III até à primeira metade do quinto (Figura 4) (Amaral, 2007; Machado, 2017).

Apesar do fim da administração romana no noroeste da Península Ibérica nos inícios do século V, a cidade continuou a ter moedas cunhadas sob os signa dos Augustos de Roma e Constantinopla ao longo da primeira metade desta centúria, embora em número bastante reduzido. De facto, objetos que ostentam as efígies de Honorius, Valentinianus III e mesmo Arcadius foram identificadas em ocultamentos monetários, cujas emissões mais recentes contemplam a primeira metade da quinta centúria (Machado, 2017).

Por outro lado, no que toca ao período de ocupação sueva, sobretudo, mas também visigótica, a investigação sobre a natureza e os processos monetários e financeiros encontram maiores obstáculos, o que resulta em um reduzido número de trabalhos realizados. Com efeito, dentre todos os períodos históricos, o reino Suevo é dos mais difíceis de se analisar, e as moedas cunhadas ao longo dos quase dois séculos em que ocupou o noroeste da Península Ibérica são um tema ainda mais complicado. A isso deve-se, em primeiro lugar, ao baixo número de exemplares identificados até ao momento, que somam quase duas centenas, e por outro lado, a ausência de contexto estratigráfico da maioria destes objetos (Cabral \& Metcalf, 1997).

Atéao momento, não foi identificada nenhuma moeda desse período em escavações realizadas em Braga, apesar de Bracara ter sido uma das principais cidades a cunhá-las, facto que nos impossibilita de conhecer a circulação monetária bracarense nesses séculos.

Contudo, se a nível económico os entraves são significativos, o mesmo não se dá a nível social. Uma vez que Braga foi a capital do reino Suevo, as emissões realizadas nesse período refletem diretamente os interesses comunicativos de sua corte ao veicularem signa, visuais e escritos, que afirmam identitariamente aquele povo ao passo que incorpora mensagens bastante claras aos demais reinos germânicos e ao imperador em Roma. Neste sentido, é notável que as primeiras emissões em prata (Figura 5), as siliquae de Requiário (448-456), ostentam no anver- so o busto do imperador Honorius (394-423) com a fórmula $D$ N HONORIVS P F AVG, enquanto no reverso temos representado uma cruz envolta em uma coroa e a expressão IVSSV RICHIARI REGES (Pliego, 2017).

Apesar de Honório ter falecido vinte e cinco anos antes do início do reinado de Requiário, este entende necessário vincular o seu nome à imagem deste imperador, sendo este, ainda, outro fenómeno bastante significativo. Com efeito, o rei suevo (rex) não tem representado o seu busto na moeda, mas sim o imperador, numa composição imagética deveras aproximada, seja nas imagens centradas, seja na disposição das fórmulas epigráficas que as envolvem. Neste processo de justaposição orientado pela rotação do objeto, os nomes próprios (HONORIVS e RICHIA$R I$ ) aparecem no mesmo lugar, o mesmo acontecendo com as evocações Pius, Felix e Augustus do romano com o Rex do bracarense (López Sánchez, 2010).

\section{IMPORTAÇÕES}

Enquanto a cidade mantinha as atividades produtivas e económicas a nível regional com uma dinâmica bastante intensa ao longo do período tardio, as rotas comerciais a nível peninsular e mediterrânico também se mantiveram ativas.

Em relação às importações peninsulares destacamos as terrae sigillatae hispânicas tardias e contentores anfóricos da Bética e de San Martiño de Bueu (Pontevedra, Galiza), cujas principais formas também foram alvo de imitações em produções locais de cerâmica de engobe vermelho e cinzenta tardia, estando representadas por pratos (Drag. 15/17, Hisp. 83B, Hayes 42 e 76), tigelas (Ritt. 8, Hayes 61B) e taças (Drag. 37, Hayes 12/102), cujas cronologias vão desde os finais do século III até aos finais do VI, com o auge das importações tendo ocorrido entre meados da quarta centúria até os inícios da sexta. Contudo, assume-se que, no caso das imitações desses objetos, é possível que tenham ocorrido em um tempo mais lato, avançando para o século VII (Ribeiro \& alii, 2014; Fernández Fernández \& Morais, 2017; Martínez Peñín \& alii, 2018).

Por outro lado, também são identificados objetos cujo centro de produção é externo à Península Ibérica, de que são exemplo os recipientes em terrae sigillatae gálica e africana tardias e LRC, cuja representação numérica na cidade não é tão substancial como as hispânicas, com exceção das africanas. Inseridos 
nessas rotas comerciais mediterrânicas também estão presentes os géneros alimentares, patentes na presença de contentores anfóricos provenientes do norte da África, Gália e de províncias orientais, para além das LRC (Martínez Peñín, Magalhães \& Martins, 2014; Martínez Peñín \& alii, 2018).

Se as importações de recipientes cerâmicos, sejam finos para usos de mesa ou anfóricos, atestam a permanência das rotas comerciais atlânticas ao longo da Antiguidade Tardia, o mesmo também é documentado a nível do material vítreo. Com efeito, foram identificados fragmentos de vidro bruto, cujas tonalidades incluem o negro opaco, castanho amarelado, verde amarelado e azul escuro, cuja presença na cidade de Bracara, sobretudo no século V, reiteram o abastecimento da cidade com essa matéria prima proveniente da costa Sírio-Palestina e do Egipto, cujo declínio apenas acontece no século VI, quando a produção secundária bracarense conhece um aumento da reciclagem para manter o seu fabrico (Cruz, 2009).

\section{CONSIDERAÇÕES FINAIS}

A divisão do tempo através de períodos cronológicos que condensem, com algum princípio de homogeneidade, os processos históricos contribuem, por um lado, para uma leitura didática e temporal dos factos, embora, por outro, inviabilizem a análise de outros fenómenos (Finley, 1989).

Isto é particularmente verdade quando observamos o fim da administração romana nas províncias da Ocidente europeu, como um todo, e a cidade de Braga, em particular. Se colocarmos como pressuposto orientador da análise a perspetiva política o ponto de viragem será a ocupação sueva da região que põe fim ao domínio do Augustus em Roma e passa a ser governada pelo rex sueborum em Bracara, refletindo-se, assim, no fim do Baixo Império Romano e iniciando-se a Alta Idade Média (Gibbon, 2014).

Por outro lado, quando a perspetiva de análise é alterada, torna-se imperativo que se discuta ou mesmo reposicione os marcos temporais que assinalam o início e o fim de períodos cronológicos. Em relação ao mesmo fenómeno, a passagem da sociedade clássica para a medieval no Ocidente europeu, uma vez que se toma para o foco da análise os processos económicos (Pirenne, 1925), as lutas sociais (Jones, 1964) ou as práticas culturais (Brown, 1971), vemos uma mudança significativa nas balizas facto-temporais.
Com este trabalho procuramos sintetizar as dinâmicas económicas de Bracara entre os séculos III e VII explorar os processos que ocorreram na cidade neste período de modo a melhor enquadrá-lo no quadro geral das discussões sobre a passagem da cidade clássica à alto-medieval. Através da análise das quatro atividades destacadas: construção, produção oleira e vítrea, circulação monetária e importações, percebemos que diversos fenómenos iniciados após o século III, ou seja, em pleno domínio romano, vão perdurar para além da ocupação sueva, nos inícios do século $\mathrm{V}$.

Nos finais do século I a.C., quando a cidade foi fundada e planificada, as ruas e quarteirões obedeciam a um rígido traçado ortogonal que exigia formas e dimensões bastante definidas, apesar do mesmo ter sido rompido pontualmente, nos inícios da segunda centúria, com a implantação do teatro, que ocupou um espaço superior a uma insula e que resultou no fechamento de três vias (Martins $\mathbb{\&}$ alii, 2013). Contudo, a partir dos finais do século III, intensificando-se no quarto e generalizando-se no quinto, vemos o progressivo avanço de unidades habitacionais sobre o espaço público, inicialmente os pórticos e depois as ruas. Se a exceção à regra dada pelo ordo decurionum para a construção do teatro teve como base o interesse pro populum, duas centúrias depois vemos a apropriação sendo realizada por paterfamiliae para o ganho privado.

Da mesma forma, as produções cerâmicas e vítreas que têm o início de seu fabrico entre os séculos III e IV, e que correspondem, necessariamente, a mudanças a nível do gosto e do interesse da população, vão conhecer uma continuidade que irrompeu, ou mesmo ignorou, o fim da administração romana, e que perdurou pelos séculos subsequentes à instalação sueva. Este fenómeno também está presente no que toca às importações, em que são documentados produtos vindos de novas regiões, como as terrae sigillatae africanas, ou de produtos oriundos de centros que já comerciavam com a Bracara Augusta do Principado, como as olarias de terra sigillatae hispânicas e gálicas, mas cujos objetos são significativamente distintos dos seus percursores, sobretudo a nível do acabamento, patente nas alterações cromáticas das superfícies das TSHT, ou como o vidro bruto importado da costa Sírio-Palestina e do Egipto, que assumem tons mais escuros como o amarelo acastanhado ou mesmo o negro.

Por fim, concluímos que esse cenário, marcado por 
uma frequente continuidade de processos que se iniciaram nos séculos III e IV e que perduraram até $o$ VI e VII, produziu uma sociedade em Bracara que se apresenta bastante homogénea no recorte proposto para a Antiguidade Tardia e que difere, em distintos níveis, daquela que foi constituída durante o Principado e mesmo a medieval que a sucedeu. Apesar de pouco conhecida, seja pela falta de estudos sobre o período, que se intensifica após a instalação do reino suevo na região, seja pela ausência de fontes documentais escritas ou a descontextualização de grande parte de seus vestígios arqueológicos, a Antiguidade Tardia em Bracara assume-se como um período bastante rico social e economicamente e basilar para a constituição do medievo bracarense e a afirmação do arcebispado de Braga.

\section{BIBLIOGRAFIA}

AMARAL, Luís (2007) - As moedas das Carvalheiras. Contributo para o estudo da circulação monetária em Bracara Augusta. Braga: UAUM/Narq (Bracara Augusta: Escavações Arqueológicas; 3 ).

BROWN, Peter (1971) - The World of Late Antiquity. London: Thames and Hudson.

CABRAL, João; METCALF, David (1997) - A moeda sueva: Suevic coinage. Porto: Sociedade Portuguesa de Numismática (Nummus Anexos; 4).

CRUZ, Mário (2008) - Black glass jewellery from Bracara Augusta. In Analles du iłe congrès de l'AIHV. Antuérpia: AIHV, pp. 96-102.

CRUZ, Mário (2009) - O Vidro Romano no Noroeste Peninsular. Um olhar a partir de Bracara Augusta. Braga: Universidade do Minho (Tese de Doutoramento).

CRUZ, Mário (2011) - Fragmentos de vidro, fragmentos da memória. Aproximação à actividade vidreira em Bracara Augusta. Cultura, Espaço \& Memória. Porto. 2, pp. 83-94

DE BLOIS, Lukas (2019) - Image and Reality of Roman Imperial Power in the Third Century AD: The Impact of War. London and New York: Routledge Taylor \& Francis Group.

DELGADO, Manuela (1993-94) - Noticia sobre cerâmica de engobe vermelho não vitricável encontradas em Braga. Cadernos de Arqueologia. Braga. № 10-11, pp. 113-152.

DELGADO, Manuela; MORAIS, Rui (2009) - Guia das cerâmicas de produção local de Bracara Augusta. Braga: CITCEM.

FERNÁNDEZ FERNÁNDEZ, Adolfo (2013) - O comercio tardoantigo no Noroeste Peninsular. Unha análise da gallaecia sueva e visigoda a través do rexistro arqueolóxico. Galícia: Editorial Toxosoutos (Trivium; 48).
FERNÁNDEZ FERNÁNDEZ, Adolfo (2017) - El comercio en el noroeste peninsular en época tardoantigua (siglos IV al VII). In LÓPEZ QUIROGA, Jorge, coord. - In tempore sueborum: El tiempo de los suevos en la Gallaecia (411-585). El primer reino medieval de occidente: Volumen de estudios. Ourense: Deputación Provincial de Ourense, pp. 317-330.

FERNÁNDEZ FERNÁNDEZ, Adolfo; BARTOLOMÉ ABRAIRA, Roberto; FOLGUEIRA CASTRO, Adrián; ALCORTA IRASTORZA, Enrique (2019) - Horizontes cerámicos tardoantiguos en Punta Atalaia (Cervo-Lugo): Una revisión del comercio cantábrico entre los siglos IV al VI. Anejos de Nailos. Oviedo. 5, pp. 551-6o2.

FERNÁNDEZ FERNÁNDEZ, Adolfo; MORAIS, Rui (2017) - Las ánforas tardoantiguas de San Martiño de Bueu (MR 7): el primer centro de producción de ánforas del noroeste de Hispania, In DIXNEUF, Delphine, ed. - La céramique commune, la céramique culinaire et les amphores de l'Antiquité tardive en Méditerranée: Archéologie et archéométrie. Alexandria: Centre d'Études Alexandrines, pp. 117-129.

FINLEY, Moses. (1989) - Uso e Abuso da História. São Paulo: Martins Fontes.

GASPAR, Alexandra (200o) - Contribuição para o estudo das Cerâmicas Cinzentas dos séculos V-VI d. C. de Braga. Braga: Universidade do Minho (Dissertação de Mestrado).

GIBBON, Edward (2014) - Declínio e Queda do Império Romano. Lisboa: Letras Itinerantes.

GOMES, Ana (200o) - Cerâmicas pintadas de época romana: tecnologia, morfologia e cronologia. Braga: Universidade do Minho (Dissertação de Mestrado).

JONES, Arnold (1964) - The Later Roman Empire.284-6o2. Cambridge: Cambridge University Press.

LEITE, Felisbela (1997) - Contribuição para o estudo da cerâmica fina de Braga: a cerâmica 'dita Bracarense'. Braga: Universidade do Minho (Dissertação de Mestrado).

LEMOS, Francisco;LEITE,José;CUNHA,Armandino(2007) - A muralha romana (Baixo Império) de Bracara Augusta, In RODRÍGUEZ COLMENERO, Antonio; RODÁ DE LLANZA, Isabel, eds. - Actas del Congreso Internacional Murallas de ciudades romanas en el Occidente del Imperio: Lucus Augusti como paradigma. Lugo: Museo Provincial de Lugo \& Deputación de Lugo, pp. 129-341.

LÓPEZ SÁNCHEZ, Fernando (2010) - Suevic coins and Suevic kings (418-456): the Visigothic connection. In CURTA, Florin ed. - Neglected Barbarians. Turnhout: Brepols Publishers (Studies in the Early Middle Ages; 32), pp. 503-536.

MACHADO, Diego (2017) - Tesouros numismáticos baixo-imperiais de contextos domésticos de Bracara Augusta. Braga: Universidade do Minho (Dissertação de Mestrado).

MAGALHÃES, Fernanda (2010) - Arquitectura doméstica em Bracara Augusta. Braga: Universidade do Minho (Dissertação de Mestrado). 
MAGALHÃES, Fernanda (2019) - A domus Romana no Noroeste Peninsular: Construção, Arquitetura e Sociabilidades. Braga: Universidade do Minho (Tese de Doutoramento).

MARTÍNEZ PEÑÍN, Raquel; MAGALHÃES, Fernanda; MARTINS, Manuela (2014) - Contribución de las producciones de cerâmica tardoantiguas para el estúdio de la ciudad de Braga. Oppidum. Porto. 7, pp. 11-28.

MARTÍNEZ PEÑÍN, Raquel; MARTINS, Manuela (2016) Characterization of late antique and Early Medieval pottery production of the city of Braga and its territory. In SABATÉ, Flocel; BRUFAL, Jesús, dirs. - Arqueologia Medieval. Hàbitats Medievals. Lleida: Pagès editors, pp. 53-67.

MARTÍNEZ PENIÍN, Raquel; MARTINS, Manuela; MAGALHÃES, Fernanda; RIBEIRO, Jorge; BRAGA, Cristina (2018) - Estudio preliminar de las producciones cerámicas tardías localizadas en el teatro romano de Braga (Portugal). In MARTÍN VISO, Iñaki; FUENTES MELGAR, Patricia; SASTRE BLANCO, José; CATALÁN RAMOS, Raúl, coords. - Cerámicas altomedievales en Hispania y su entorno (siglos V-VIII d.C.). Espanha, Glyphos, pp. 189-209.

MARTINS, Manuela (2005) - As termas romanas do Alto da Cividade: Um exemplo de arquitectura pública em Bracara Augusta, Braga: UAUM/Narq (Bracara Augusta: Escavações Arqueológicas; 1).

MARTINS, Manuela; MAGALHÃES, Fernanda; BOTICA, Natália (2018) - O urbanismo fundacional de Bracara Augusta e Lucus Augusti. In DOPICO CAÍNZOS, María; VILLANUEVA ACUÑA, Manuela, eds. - Sine iniura in pacer vivatur: A constución do Imperio durante os xulio-claudios. Lugo: Servizo de Publicacións da Deputación de Lugo (Philtáte. Studia et acta antiquae Callaeciae; Vol. 3), pp. 345-373.

MARTINS, Manuela; FONTES, Luís; BRAGA, Cristina; BRAGA, José; MAGALHÃES, Fernanda; SENDAS, José (2009) - Relatório final dos trabalhos arqueológicos realizados no Quarteirão dos CTT - Avenida da Liberdade. Braga: UAUM (Memórias 1).

MARTINS, Manuela; MAGALHÃES, Fernanda; MARTÍNEZ PEÑÍN, Raquel; RIBEIRO, Jorge (2016) - The housing evolution of Braga between Late Antiquity and the Early Middle Ages. Arqueología Medieval. Lleida. VIII, pp. 35-52.

MARTINS, Manuela; MAR, Ricardo; RIBEIRO, Jorge; MAGALHÃES, Fernanda (2013) - A construção do teatro romano de Bracara Augusta. In MELO, Arnaldo; RIBEIRO, Maria, orgs. - História da Construção. Arquiteturas e Técnicas Construtivas. Braga: CITCEM, pp. 41-74.

MARTINS, Manuela; RIBEIRO, Jorge; MAGALHÃES, Fernanda; BRAGA, Cristina; RIBEIRO, Maria (2017b) - O espaço construído de Bracara Augusta no Alto Império. In DOPICO CAÍNZOS, María; VILLANUEVA ACUÑA, Manuel, eds. - In Roma nata, per Italiam fusa, in provincias manat. A cidade romana no noroeste: novas perspectivas. Lugo: Servizo de Publicacións da Deputación de Lugo (Philtáte. Studia et acta antiquae Callaeciae; Vol. 2), pp. 251-276.
MARTINS Manuela; RIBEIRO Jorge; MAGALHÃES Fernanda; MARTÍNEZ PEÑÍN, Raquel (2015) - Urban changes in Braga in Late Antiquity: the area of the Roman Theater. In MARTÍNEZ PENIÍN, Raquel, org. - Braga and its territory between the fifth and the fifteenth centuries. Lleida/Braga: UAUM \& Universitat de Lleida (Espai/temps; 67), pp. 11-28.

MARTINS, Manuela; RIBEIRO, Maria; RIBEIRO, Jorge; MAR, Ricardo (2017a) - Topografia e urbanismo fundacional de Bracara Augusta. In DOPICO CAÍNZOS, María; VILLANUEVA ACUÑA, Manuel, eds. - In Roma nata, per Italiam fusa, in provincias manat. A cidade romana no noroeste: novas perspectivas. Lugo: Servizo de Publicacións da Deputación de Lugo (Philtáte. Studia et acta antiquae Callaeciae; Vol. 2), pp. 203-226.

MORAIS, Rui (2001) - Breve ensaio sobre o anfiteatro de Bracara Augusta. Forum. Braga. 30, pp. 55-76.

MORAIS, Rui; SOEIRO, Teresa; FERNÁNDEZ FERNÁNDEZ, Adolfo; SOUSA, Maria (2014) - As cerâmicas de engobe branco de época imperial no Noroeste Peninsular. In MORAIS, Rui; FERNÁNDEZ FERNÁNDEZ, Adolfo; SOUSA, Maria, eds. - As produções cerâmicas de imitação na Hispania. Porto: FLUP (Monografias Ex Officina Hispana; II), pp. 361-368.

PEREIRA, Felipe (2018) - A Zona Arqueológica do Fujacal e os impactos urbanísticos e topográficos da construção da muralha romana de Bracara Augusta. Braga: Universidade do Minho (Dissertação de Mestrado).

PIRENNE, Henri (1925) - Medieval Cities: their origins and the revival of trade. Princeton: Princeton University Press.

PLIEGO, Ruth (2017) - La moneda de época sueva: Un destello fugaz en la historia monetaria de Gallaecia. In LÓPEZ QUIROGA, Jorge, coord. - In tempore sueborum: El tiempo de los suevos en la Gallaecia (411-585). El primer reino medieval de occidente: Volumen de estudios. Ourense: Deputación Provincial de Ourense, pp. 145-156.

RIBEIRO, Jorge (2010) - A Arquitectura romana de Bracara Augusta. Uma análise das técnicas edilícia. Braga: Universidade do Minho (Tese de Doutoramento).

RIBEIRO, Jorge; FERNÁNDEZ FERNÁNDEZ, Adolfo; CUNHA, Armandino; MARTINS, Manuela; MAGALHÃES, Fernanda; BRAGA, Cristina (2014) - A cerâmica romana do balneário da rua D. Afonso Henriques: estudo preliminar da sequenciação cronológica e ocupacional do edifício (Braga, Portugal). In MORAIS, Rui; FERNÁNDEZ FERNÁNDEZ, Adolfo; SOUSA, Maria, eds. - As produções cerâmicas de imitação na Hispania. Porto: FLUP (Monografias Ex Officina Hispana; II), pp. 361-368.

RIBEIRO, Maria; MARTINS, Manuela (2018) - A cidade nas encruzilhadas da história. Evolução urbana de uma cidade com 2000 mil anos: Braga (Noroeste de Portugal). Dimensões. Espírito Santo. V. 4O, pp. 11-38. 
RIPOLLÈS ALEGRE, Pere (2002) - La moneda romana imperial y su circulación en Hispania. AespA. Madrid. 75, pp. 195-214.

RUIVO, José (2008) - Circulação monetária na Lusitania do século III. Porto: Universidade do Porto (Tese de Doutoramento).

VILA FRANCO, María (2012) - La monetización del noroeste de la Península Ibérica a través de la red viaria terrestre en época romana. Santiago de Compostela: Universidade de Santiago de Compostela (Tese de Doutoramento).

ZABALETA ESTEVÉZ, María (1999) - Breve síntese sobre os estudos das moedas de Bracara Augusta - as moedas das termas do Alto da Cividade. Forum. Braga. 26, pp. 8o-85.

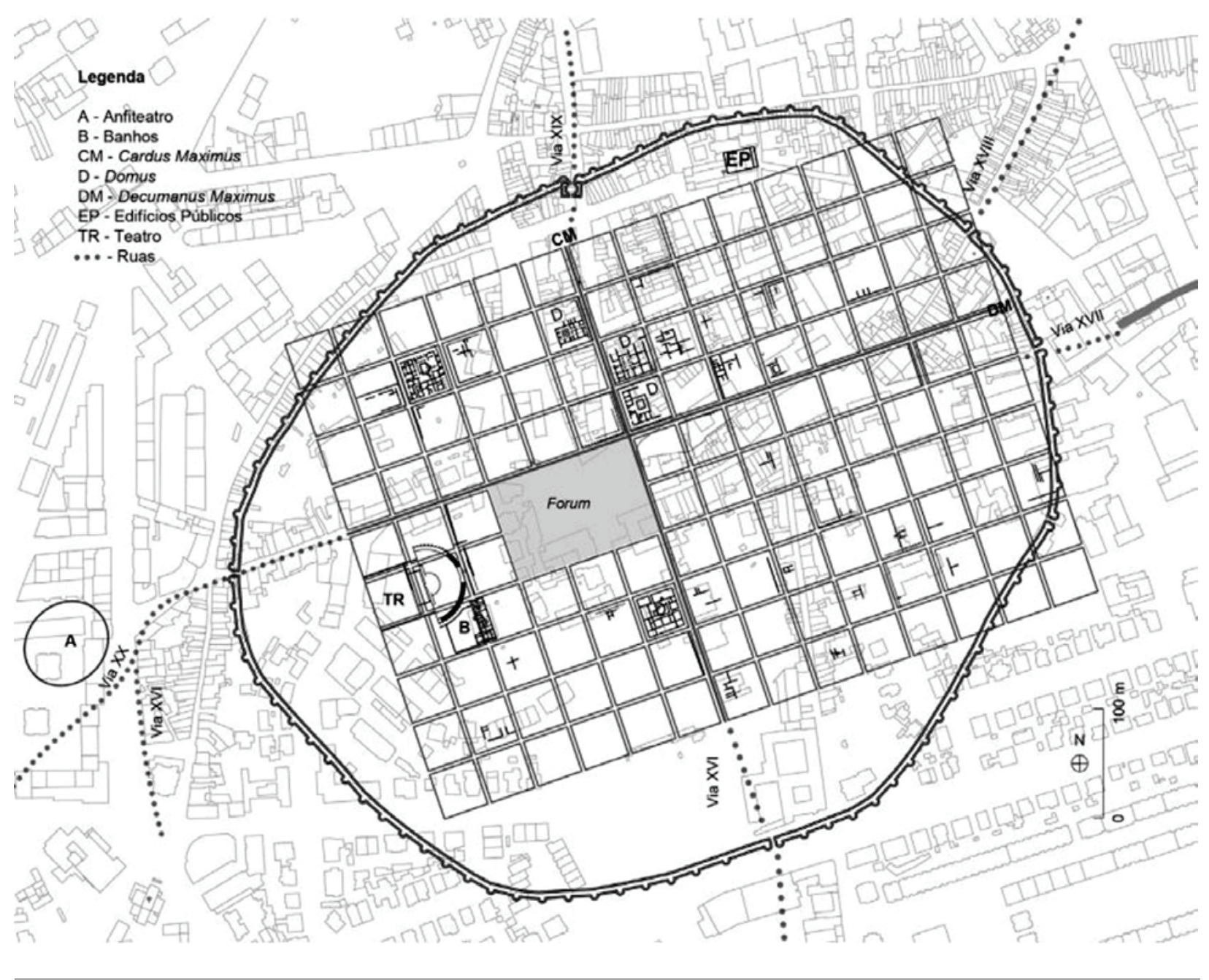

Figura 1 - Planta de Bracara Augusta no século IV (Ribeiro \& Martins, 2018). 

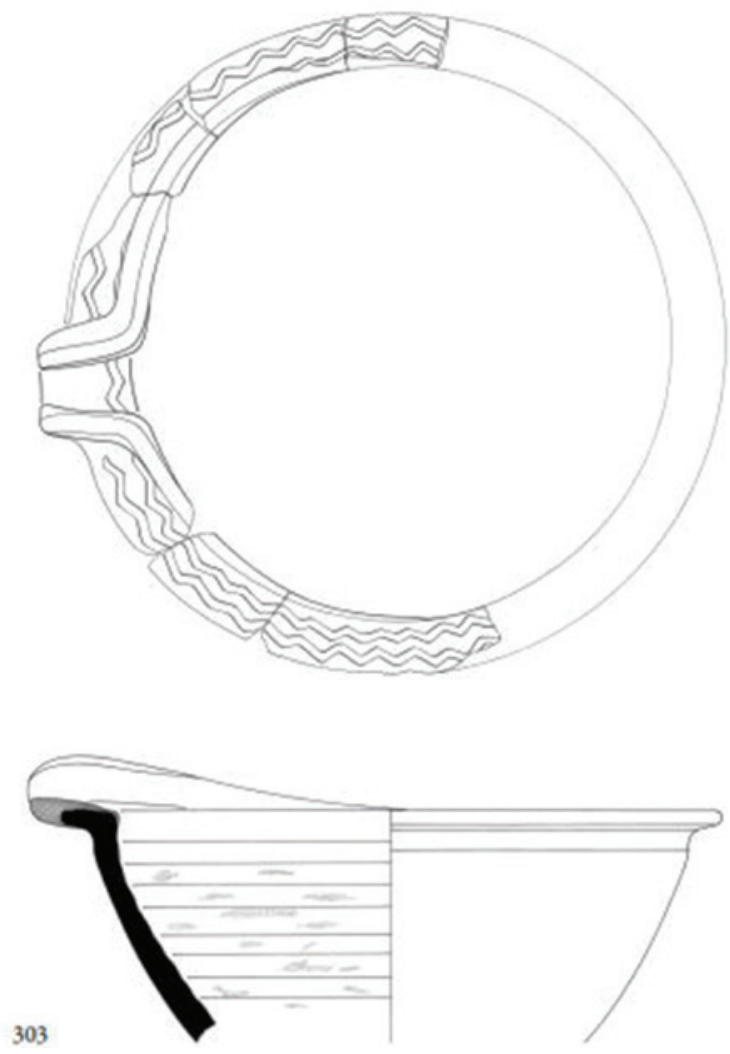

Figura 2-Almofariz vidrado tardio de Bracara (Delgado \& Morais, 2009).

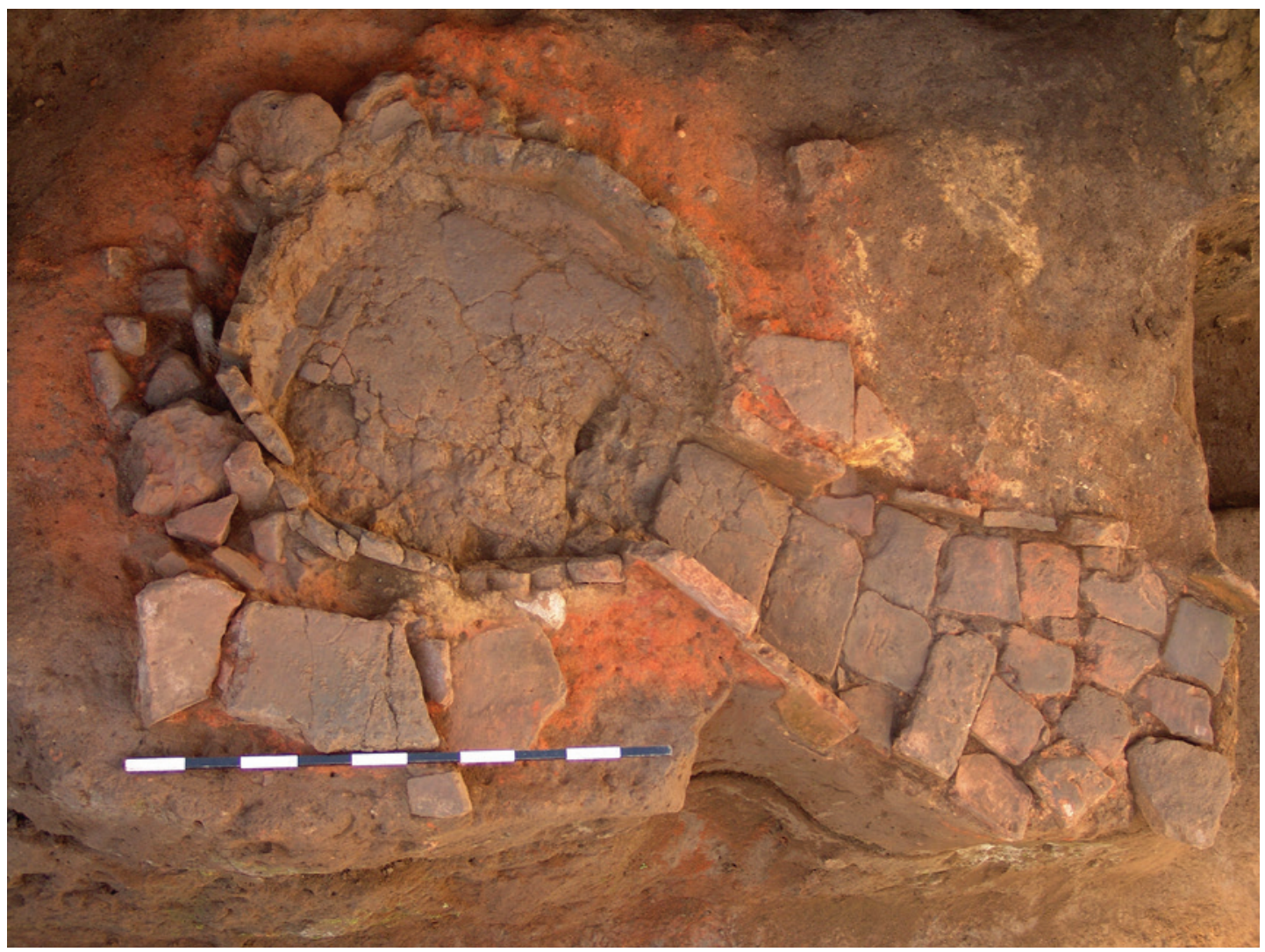

Figura 3 - Forno de produção vítrea dos CTT (C UAUM). 


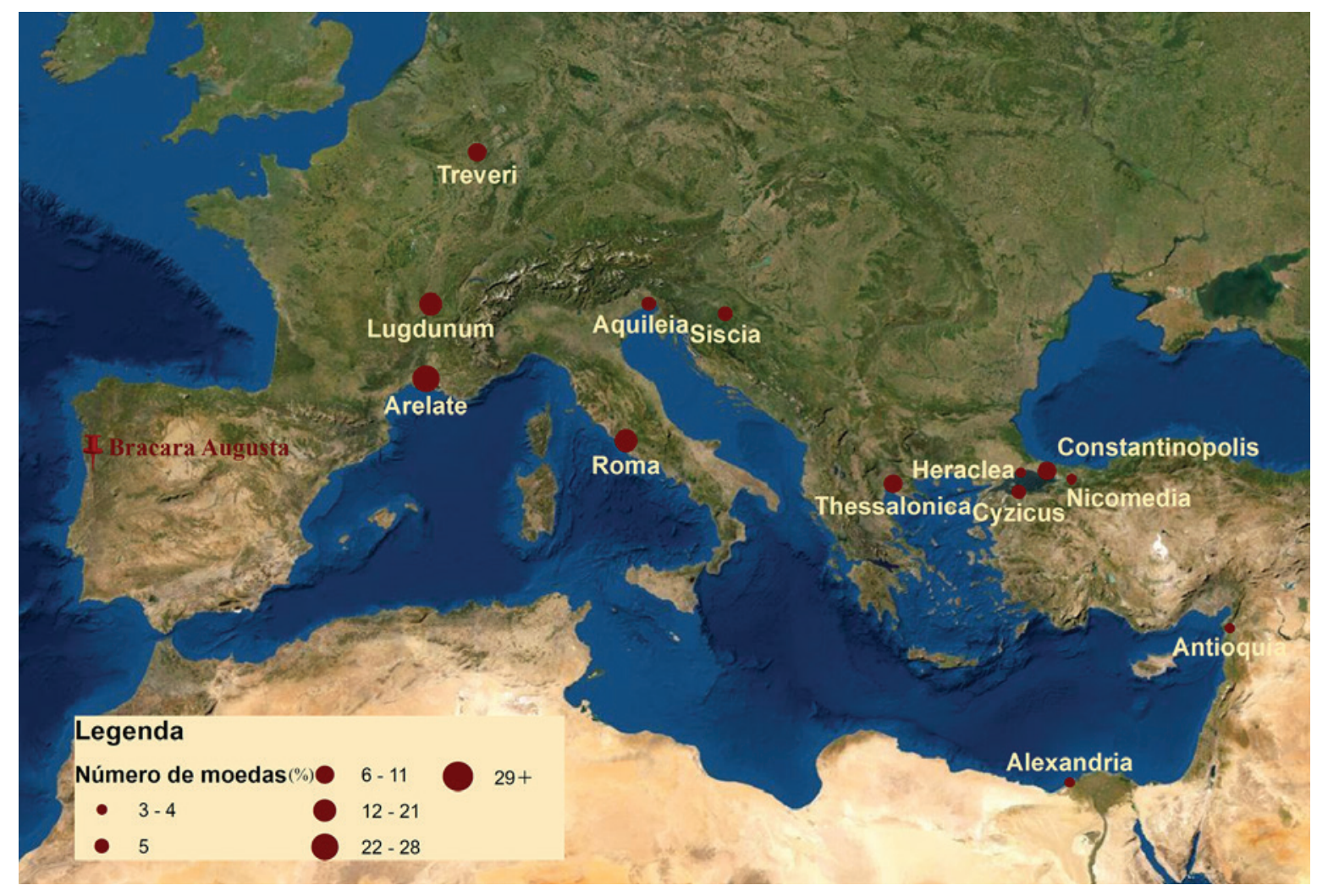

Figura 4 - Mapa com a distribuição das casas de cunhagem que compõem o tesouro da domus de Santiago (C UAUM).
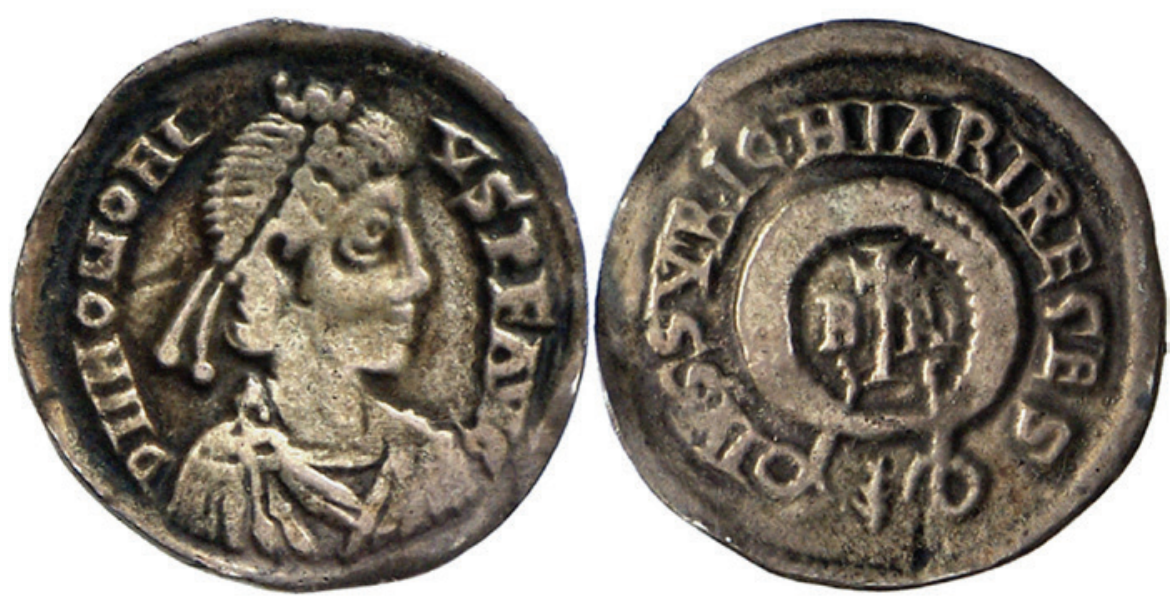

Figura 5-Siliqua de Requiário ( Münzkabinett, Staatliche Museen zu Berlin). 



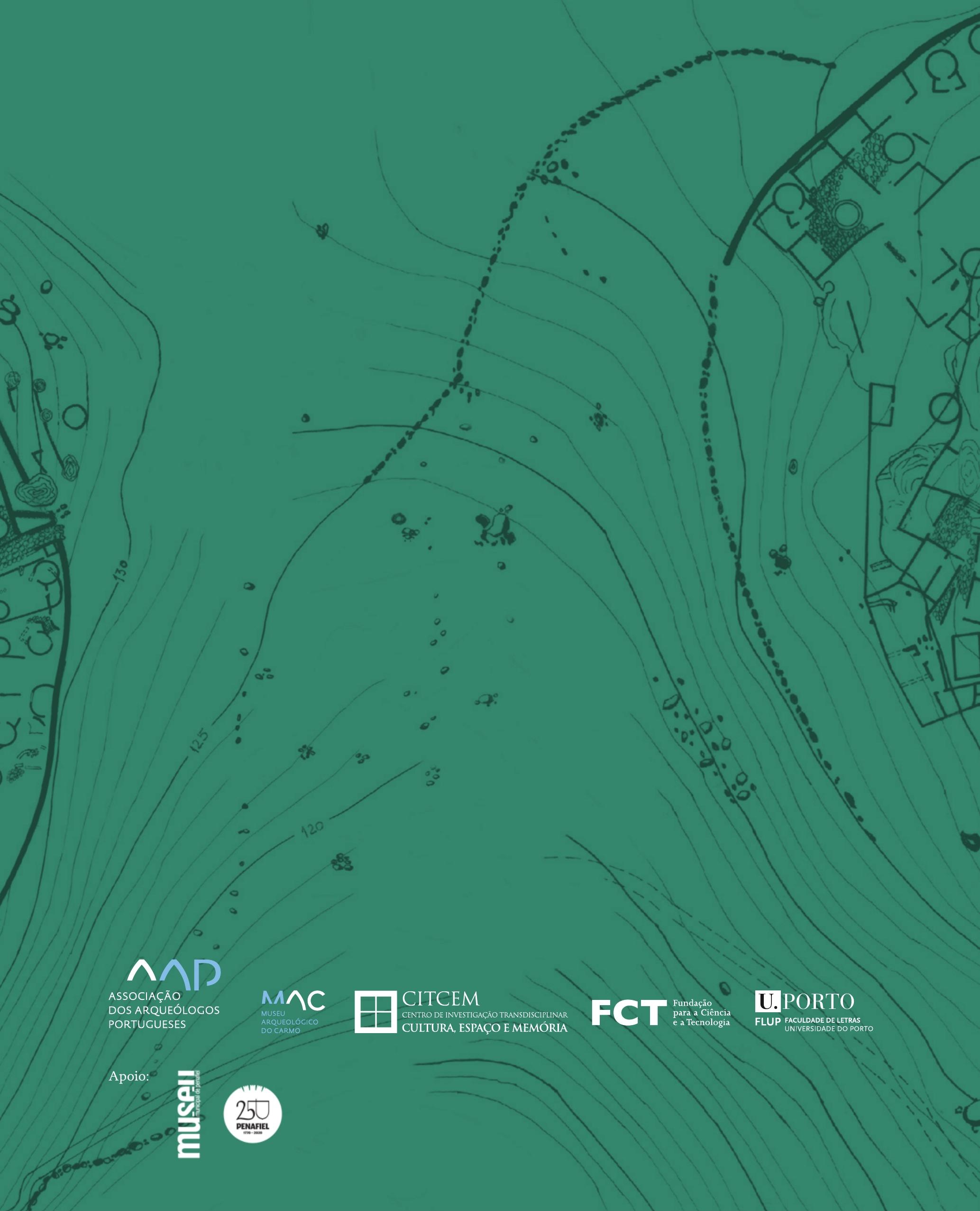

